\title{
Oxygen Uptake and Spectrophotometric Measurement of Superoxide, Hydrogen Peroxide and Hydroxyl Radicals
}

\section{Hideharu Shintani*}

Chuo University, School of Science, 1-13-27, Kasuga Bunkyo 112-0003 Tokyo, Japan

Keywords: Oxygen uptake; Spectrophotometric measurement; Superoxide anion radicals; Hydrogen peroxide; Hydroxy radicals

\section{Introduction}

The uptake or evolution of oxygen during a reaction can be monitored by use of a Clark-type electrode. The method is particularly useful when turbidity or interfering chromogens preclude the use of spectrophotometry [1]

\section{Protocol}

\section{Electrode calibration}

1. Add deionized water $(2 \mathrm{~mL})$ to the temperature-controller reaction chamber with magnetic stirring, and apply $0.7 \mathrm{~V}$ across the electrodes.

2. An output of 0.1 to $10 \mathrm{mV}$ is used with a chart recorder set to a value of $100 \%$.

3. Leave electrode to settle for $5 \mathrm{~min}$.

4. Add a few crystals of sodium dithionate to remove $\mathrm{O}_{2}$

5. This value represents $0 \% \mathrm{O}_{2}$. The electrode is now calibrated from 0 to $100 \%$ oxygen.

6. Apply test samples to chamber after carefully washing each time.

\section{Calculation}

The concentration of oxygen can be calculated by use of the information that air-saturated water at $30^{\circ} \mathrm{C}$ contains $0.460 \mu \mathrm{ml} \mathrm{O}$.

\section{Spectrophotornetric Measurement of Superoxide Anion Radicals}

First applied to neutrophil studies in 1968, the nitroblue tetrazolium (NBT) test provides a simple assay for $\mathrm{O}_{2}$ production. $\mathrm{NBT}$ is reduced by $\mathrm{O}_{2}^{-}$to a blue formazan product which is measured at $620 \mathrm{~nm}$. Spectrophotometric assay techniques are covered in full $[2,3]$. Pulse radiolysis techniques are also described [4]

\section{Spectrophotornetric Measurement of Hydrogen Peroxide}

Any system producing $\mathrm{O}_{2}^{-}$will also produce $\mathrm{H}_{2} \mathrm{O}_{2}$ by the dismutation reaction. $\mathrm{H}_{2} \mathrm{O}_{2}$ is an uncharged molecule that can readily enter cells as a water look-alike. Most assays utilize a peroxidase with coupled oxidation of a detector molecule.

$\mathrm{H}_{2} \mathrm{O}_{2}$ can also be determined by measuring the loss of scopoletin fluorescence $(460 \mathrm{~nm})$, an assay covered in detail [5] or on the basis of its reaction with cytochrome-c peroxidase to form a stable complex with absorbance at $419 \mathrm{~nm}\left(\mathrm{~A}_{419}\right)$ [1]

Herein we describe a method using phenol red to measure hydrogen peroxide in breath condensates [6].

\section{Protocol}

1. Dilute stock hydrogen peroxide (30\% v/v) 1:1000 with Chelex resin treated distilled water.

2. Calculate the concentration of $\mathrm{H}_{2} \mathrm{O}_{2}$ by measuring absorbance at $240 \mathrm{~nm}$ using a molar absorption coefficient of $43.6 \mathrm{M} / \mathrm{cm}$.

3. Prepare buffered phenol red-peroxidase reagent containing $\mathrm{NaCl}(40 \mathrm{mM})$, potassium phosphate $(\mathrm{pH} 7.0,10 \mathrm{mM})$, phenol red $(0.1 \mathrm{~g} / \mathrm{L})$, and horseradish peroxifase (HRPO; $8.5 \mathrm{unit} / \mathrm{mL}$ ), adding phenol red and HRPO to buffer just before use.

4. To $1.0 \mathrm{~mL}$ phenol red reagent add $0.5 \mathrm{~mL}$ breath condensate. Hydrogen peroxide standards are similarly treated.

5. Mix and stand for $5 \mathrm{~min}$ at $25^{\circ} \mathrm{C}$.

6. Add $\mathrm{NaOH}(1 \mathrm{M}, 10 \mu \mathrm{L})$ to give a $\mathrm{pH}$ of 12.5 and a stable purple color.

7. Measure absorbance at $610 \mathrm{~nm}$.

\section{Calculation}

Include a blank containing $\mathrm{H}_{2} \mathrm{O}_{2}$-free water and calculate values from an $\mathrm{H}_{2} \mathrm{O}_{2}$ standard curve.

\section{Spectrophotometric Measurement of Hydroxy Radical Damage}

The hydroxyl radical is much too reactive to be measured directly by simple spectrophotometric techniques. Evidence characteristic of its damage is, therefore, usually sought by use of a detection molecular for such damage. Here we describe the use of the sugar 2-deoxy-D-ribose [7-9].

\section{Protocol}

1. Into clean glass tubes place 5-deoxy-D-robose ( $5 \mathrm{mM}, 0.2 \mathrm{~mL})$ and sodium phosphate buffer $(0.024 \mathrm{M}$ containing $0.15 \mathrm{M}$ $\mathrm{NaCl}, \mathrm{pH}$ 7.4, $0.2 \mathrm{~mL}$.

2. Add $\mathrm{OH}$ generating system, i.e.;

[A] $0.1 \mathrm{~mL}$ of ferrous salt (freshly prepared at $\mathrm{pH}<6.0$ ) or

*Corresponding author: Hideharu Shintani, Chuo University, School of Science 1-13-27, Kasuga Bunkyo 112-0003 Tokyo, Japan, Tel: +81425922336; E-mail: shintani@mail.hinocatv.ne.jp

Received May 21, 2013; Accepted June 12, 2013; Published June 15, 2013

Citation: Shintani H (2013) Oxygen Uptake and Spectrophotometric Measurement of Superoxide, Hydrogen Peroxide and Hydroxyl Radicals. Pharm Anal Acta S7: 005. doi:10.4172/2153-2435.S7-005

Copyright: (c) 2013 Shintani H. This is an open-access article distributed unde the terms of the Creative Commons Attribution License, which permits unrestricted use, distribution, and reproduction in any medium, provided the original author and source are credited. 
Citation: Shintani H (2013) Oxygen Uptake and Spectrophotometric Measurement of Superoxide, Hydrogen Peroxide and Hydroxyl Radicals. Pharm Anal Acta S7: 005. doi:10.4172/2153-2435.S7-005

Page 2 of 2

[B] ferric-EDTA + ascorbate or

[C] hypoxanthine + xanthine oxidase + ferric salt.

3. Incubate reactants for $30 \mathrm{~min}$ at $37^{\circ} \mathrm{C}$.

4. Add thiobarbituric acid $(1 \% \mathrm{w} / \mathrm{v}, 0.5 \mathrm{~mL})$ and trichloroacetic acid $(2.8 \% \mathrm{~W} / \mathrm{V}, 0.5 \mathrm{~mL})$.

5. Heat tube contents at $100^{\circ} \mathrm{C}$ for $10 \mathrm{~min}$.

6. Cool and read absorbance at $532 \mathrm{~nm}$ or fluorescence at 553 $\mathrm{nm}$ after excitation at $532 \mathrm{~nm}$.

\section{Calculation}

The assessment of $\mathrm{OH}$ damage can be used to test the effectiveness of scavengers and inhibitors, and to determine second-order rate constants for reaction of $\mathrm{OH}$. with various scavenger.

\section{Comments}

$\mathrm{OH}^{*}$ generating systems $[\mathrm{A}]$ and $[\mathrm{B}]$ are not inhibited by $\mathrm{SCD}$, whereas $[\mathrm{C}]$ is. All three $\mathrm{OH}$-generating ststems should be inhibited by catalase or other $\mathrm{H}_{2} \mathrm{O}_{2}$ renoving enzymes. If silutions are turbid extract chromogen into butan-1-ol.

\section{References}

1. Trudgill PW (1985) Oxygen Consumption. In Cell CRC Handbook of Methods of Methods for Oxygen Radical Research, CRC Press, Boca Raton, USA 329-42.

2. Rice Evans CA, Diplock AT, Symons MCR. (1991) Techniques in Free Radical Research, Elsevier Amsterdam 85-91.

3. Greenwald RA (1995) CRC Handbook of Methods for Oxygen Radical Research. CRC Press, Boca Raton, USA 85-91.

4. Punchard NA, Kelly FJ (1996) Free Radicals: A Practical Approach, IRL-Press, Oxford 11-24.

5. Rice-Evans CA, Diplock AT, Symons MCR (1991) Techniques in Free Radical Research. Elsevier, Amsterdam 91-96.

6. Pick E, Keisari Y (1980) A simple colorimetric method for the measurement of hydrogen peroxide produced by cells in culture. J Immunol Methods 38: 161 170.

7. Gutteridge JM (1981) Thiobarbituric acid-reactivity following iron-dependent free-radical damage to amino acids and carbohydrates. FEBS Lett 128: 343346.

8. Halliwell B, Gutteridge JM (1981) Formation of thiobarbituric-acid-reactive substance from deoxyribose in the presence of iron salts: the role of superoxide and hydroxyl radicals. FEBS Lett 128: 347-352.

9. Gutteridge JM (1987) Ferrous-salt-promoted damage to deoxyribose and benzoate. The increased effectiveness of hydroxyl-radical scavengers in the presence of EDTA. Biochem J 243: 709-714 